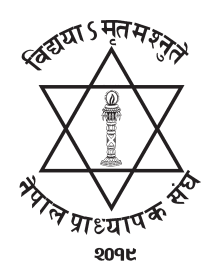

NJ: NUTA

\title{
Materialization of Love in Morrison's Love: A Marxist Perspective
}

\author{
Bimal Kishore Shrivastwa \\ Department of English, P. G. Campus, Tribhuvan University, Nepal \\ Email: bimalksrivastav@gmail.com
}

\begin{abstract}
This article attempts to explore how human beings are controlled by the material values in the society governed by the capitalistic regime in Toni Morrison's novel, Love where money and matter overshadows other moral and social customs. Fascination towards economic gain is the natural inclination of the human beings since all the capitalistic desires and provisions are generally dealt with money. The overall purpose of the study is to show how Toni Morrison's dominant characters in Love, Cosey, Heed, L and Christine are much obsessed with material success in order to capture the sordid nature of materialization of human life in the commercial world. The research methodology, used to survey the unquenched material desire of human beings such as Mr. Cosey and Christine and their degradation for it, is Marxism. Christine is ready to do everything to be a capitalistic modern. The principal finding is that in the name of love, pre-menstruated girl is made to marry an old man. She is turned into a commodity item. People are seeking mammoth pleasure but they are spiritually barren, which shows money and matter over taking the realm of love and spirituality.
\end{abstract}

Key Words: Capitalism, commodification, exploitation, materialism, sexism

\section{Introduction}

The novel, Love (2003) by Toni Morrison, but talks of love is shadowed by greed for property, jealousy, insanity and hatred. An American novelist, college professor, and a great classic in contemporary American literature for her profound studies of black ethnic culture and black feminism (Jia Yuxuan, 2020), Toni Morrison's writings always engage major contemporary social issues: the interrelatedness of racism, class exploitation and sexism, and the negotiation of slippery boundaries, especially for members of oppressed groups between personal desire and political urgencies (Wu Yung-Hsing, 2003). Her novel, Song of Solomon (1977) brought her national attention and won the National Books Critics Circle Award. In 1988, Morrison won the Pulitzer Prize for Beloved (1987); she gained worldwide recognition when she was awarded the Nobel Prize in Literature in 1993 (Margalit Fox, 2019). Awkward Michael (1990) discerns in Morrison's works a feminist version of such precursors as Ellison and Baldwin and the condition of double-consciousness and distorted sense of self. Her other novels include The Bluest Eye (1970), Sula (1974), Tar Baby (1981), Jazz (1992), God Help the Child (2015). Morrison's works are always symbolic, of the shared human condition, both engaging with and transcending lives of gender, race and class (Emily Langer, 2019, para.11). Min Pun (2017) regards that

NUTA JOURNAL, 7 (1 \& 2), 2020 : ISSN: 2616 - 017x 
Morrison's early novels dramatize the destructive effects of community on young black girls struggling toward womanhood (p. 15).) Morrison's fictions dramatize issues of boundary, attachment, separation and division (Roberta Rubenstein, 2011). Donald B. Gibson (1984) marks Morrison dramatizing the internalization of oppression of the blacks in her works. In the view of Susan Willis (1987), Morrison's abiding concern is the preservation of Afro-American folk cultures after the depression of rural. Morrison's fictions explore events that are dominations, injustices and slavery of African-American and its consequences (Aribert Schroeder, 1990).

In Morrison's Love, matter is emphasized more than spirit and social custom. By producing their means of subsistence human beings are indirectly producing their actual material life. Bill Cosey, around whom the story is woven, has been dead for twenty-five years. But he is still a very real presence to the women who shared his life. During the 1940s he became a millionaire as the owner of Cosey's Hotel and Resort, the best known vacation spot for colored folks on the east coast. Guests who come from as far away as Michigan and New York could not wait to get down here. In a time when segregation was still alive, blacks needed a place to socialize and to have fun. Bill Cosey offered them just that. He ran a profitable business where all his guests felt beloved. He was a rich black businessman, respected in the community, and above all else, a ladies' man. Respect toward Cosey was a salute to his property rather than his sexy attitude. The relationships of this ladies' man with women that surround him are the guiding elements of Morrison's novel, both thematically and formally. While during his life, these women, his wife, grandaughter, daughter-in-law, employees and others vied for his attention, following his death; their rivalries only grew stronger, as manifested by the arguments over his will. The novel's chapter titles, 'Husband', 'Lover', 'Father', 'Friend' and 'Benefactor' parallel the different ways these women characterize Bill Cosey. Even Junior, a young girl, hired as Cosey’s widow’s companion seems to worship his memory, although she never knew him in life. These women idealize Cosey as their own 'perfect man'. The women inhabit Cosey's world are Heed , his wife, the girl he married when she was eleven and how she is reclusively determined to keep the family legacy; Christine, his granddaughter who was Heed's best friend until she married Cosey and became an enemy; May, Christine's mother, Cosey's daughter-in- law and widow of his only son Billy Boy; Vida, a former employee who, while grateful to Cosey, was never fooled by him, nor did she believe he died a natural death; Celestial, his pleasure women, the only one who was able to inspire his romantic love; Junior, recently released from correctional who talks herself into a job as 'assistant' to the aging Head, who needs help with a nefarious plan; and the 'humming' voice of L, the hotel's former cook. Her presence is quite ghostly but her words as she opens and then closes the story. L's narration is the glue that holds the multiple story lines of love together.

The production of ideas, of conceptions, of consciousness, is at first directly interwoven with the material activity and the material intercourse of men, the language of real life. Conceiving, thinking, the material intercourse of human beings, appears at this stage as the direct efflux of their material behavior. The same applies to the mental production as expressed in the language of politics, law, morality, religion and metaphysics of people. For survival, a woman sleeps with a man but there the woman is wronged because she is helpless, she does not have money but the male has money. Women are compelled to adopt profession of prostitution. They are paid less than man although "when a man took a woman, he came to live in her household activities" (p. 47). Apart from L all female characters 
are used as commodity in the capitalistic society. Not only wife but daughter and other family members are taken as commodity. Christine is treated as commodity by her step mother. Junior is carried as goods by her employer. In the text of love female characters are dominated by materialistic approach by major characters; Bill Cosey and Heed. Bill Cosey, the protagonist of the novel, revolves female characters for his prosperity in Hotel business according to his will. He continuously uses female even after his death, they have to depend upon him and engage to save his properly for the name of Cosey. They are used sexually too that he marries an eleven-year old child and has secret relation with Celestial. They are compelled to be molded and commodified according to the will of male. All the female characters live and work for the sake of his property. On the one hand, Bill Cosey uses female characters for the sake of his property fame, on the other hand, female characters like Heed struggles and enemies with other for her husband and she herself is sexually exploited for pleasure for male female has to do only for their male like a worker in capitalist society.

This researcher has tried to unveil domination of human in the name of matter in an economic context in the text love by Toni Morrison. How the black people, within the same society, are being dominated in the name of conservation. They are using the norms and values constructed by themselves on the basis of power relations of materiality which have the economic basis.

\section{Literature Review}

Love has received much critical appraisals on its theme, characterization, narrative techniques since its publication. This shows richness and literary height of the text.

Speaking on the theme of the novel, Hello Thumper (2003) scrutinizes Love as human drama that is subtle in its complexities of love: parental, self, romantic and friendship. Bill Cosey was the center of the women's world. The novel is more about the interactions between the women. Mar Gallego (2007) regards that the novel basically focuses on the tragic story of the protagonist and struggle for the identity of its characters. Especially, the novel shows post civil war situation of America, how the black people are in intra-conflict in the name of civilization. Morrison's Love is an ever-moving tribute to the past all the while making evident the realities of the present. Morrison's characters are full of life, emotions, and perfect vehicles through which the complexities of human behavior are uncovered (Tessa Kate Roynoon, 2007). Katherine Lynn Fulton (2009) deems that Morrison does a fabulous job of navigating through the tale of a group of women all enamored with one man in Love. As the novel suggests love takes many shapes and can lead to an innumerable amount of relation when confronted with adversity.

Some critics have offerd notable judgements on the narrative techniques of the novel. The novel is told as series of flashback; Morrison follows the development of her characters through time, although she takes care to reveal their personalities slowly (Jean Wyatt, 2017). In her latest novel, Love, the reader is presented with a series of separate narratives each revolving around the patriarchal centre of Bill Cosey, the deceased owner of the closed Cosey Hotel and Resort (Magdalena Ball, 2004). Love continues Morrison's project of exploring African-American history and culture (Elaine Showalter, 2003). Told elliptically through the eyes of an ensemble cast, the novel recalls the life and legacy of Bill Cosey, the proprietor of a popular vacation getaway for prosperous blacks in the days before desegregation and the civil-rights movement (Keith Phillips, 2003). Critic Jonne McCarthy (2004) views that Love is about the relation of historical facts. He further states: The novel plays out against 
the back-drop of the civil right movement in the United States, from the 1995 murder of Emmett till in Mississippi through bus boycotts and church bombings to the unrest of the Vietnam. These events deeply affect May, who becomes critically paranoid, and Christine, whose lover heads up underground revolutionaries. (p. 202)

Judging on the chacacters, Ho Wen- Ching (2006) marks L as the voice of this narrative who has watched some fall a part and kept hidden the secrets about the infamous Bill Cosey. She weaves her judgments of the women: Heed, Christine, Vida, Junior, even Celestial through her series of recollections, all the while revealing her own infatuation with Bill Cosey.In the name of love and better life the non-whites have turned materialistic, unsound love affair is acquiring and people are wasting the time worthlessly.

The critics' reviews on the text, Love from various perspectives signify that they have noticed the problems of Afro-American people and the segregation on them. However, critics have not noticed the materialization of love in the text. Hence, this article aims to fulfill the research gap oriented to analyze how Toni Morrison's connects the existence of human beings in search of property with the help of artificial love of materiality.

\section{Research Methods}

The paper applies a qualitative approach to research by exploring the resource, that is, the text, Morrison's Love itself from a theoretical modality based on modern Marxist theories. And the secondary resources on this text such as literature from journals Modern Fiction Studies, International Journal of Literature and Arts, and websites on Morrison are surveyed to note the research gap. The systematic sampling method is used to justify the working hypothesis. Its delimitation primarily lies on focusing on the commidification of love, and women's endeavor to disrupt it while assessing the novel, Love. The problems the study states are what impel women to adopt prostitution or to sleep with the rich men. To analyze these problems, intensive analysis of the text is done from the theoretical modality of materialism, and neo-Marxism.

\section{Theoretical Modality}

Marxism, in literature, refers to a method of socioeconomic analysis that uses a materialist interpretation of historical development to understand to understand Class relations and social conflict to view social transformation ("Marxism", n. d.). It originates from the works of 19th-century German philosophers Karl Marx and Friedriech Engerls. Karl Marx in The Communist Manifesto (1848) makes analysis of history in terms of class struggles "The history of all hitherto existing society is the history of class struggle" (p. 21). For Marx, economic, political and social dimensions are the determinants of human consciousness such as language, law, politics, morality, religion and art.The Neo-Marxists Adorno and Horkheimer view that the basis on which technology acquires power over society is the power of those whose economic hold over society is greatest. (Adams, 1992). Adorno (1990) says that "Mass culture is seen as just another part of the apparatus which makes people submit to the imperative of the economic system" (p. xix). Louis Althusser (1970) states that no production is possible if that does not allow for the reproduction of the material conditions of production. Materialistic people believe that having money and possession is the most important thing in life. It directly relates to physical objects rather than emotions or the spiritual world (Parvini, 2012). Thus, it is challenging and interesting to mark how the capitalistic society silently makes people material and treats culture as goods of pleasure in the novel Love by Toni Morrison. 


\section{Discussion}

The novel, Love (2003) by Toni Morrison, talks of love as shadowed by greed for property, jealousy, insanity and hatred. In the world of commerce and capitalism, human beings are identified through their power of affording money and different essentialities. Human and other moral values are discarded, and are insignificantly overlooked. Morrison expresses the topic by literalizing love not merely as an emotion, not what one purportedly feels towards another; rather, she portrays love as an act, leading to the question: how does one “do love?" (p. 2) Morrison's repeated use of hands as a leitmotif in Love foregrounds the action of love, the materiality of love.

Heed, the daughter of Bill Cosey, black rich man, enters in the world of funny and holiday resorts where in only possessive has property. Bill Cosey, the former owner of Cosey's Hotel and Resort, was a wealthy and powerful man whose acts of love and violence, generosity and cruelty, structure the novel. As a free man, his love is never safe, and indeed he and his legacy ruin the lives of the women in his inner circle. Years after Cosey's death, the women are still obsessed with him, suggesting that death does not stop love but the purpose is to grab his property. It illustrates the effect of the changing economic structure and materialistic world of the then African-American culture; Heed is the one of the thousands of poor ladies who seeks the property during the post-war era. One of the biggest changes in the American culture was overwhelming emphasis on 'making property' or the one seeking of money in such a way that one's love being a lover and beloved becomes immediate evident. The new approach of material world is castling love and pleasure, in social assistance and relation all other ideas form, including those of business and, of economy, morality etc. Materialism is a philosophy of the subject who forgets to take account of himself/herself (George Manbiot, 2013). Everything is matter and object for materialistic people. In most of religion: Hinduism, Buddhism, Christianity, Islam, all mater is believed to be an illusion called 'Maya' and 'love', binding us from knowing the truth. But it changes the mind of people according to time and necessity. Morrison amplifies this argument in Love in which hands--their materiality, their work, and their transformation--bespeak characters. The twelve diamond rings - "two on three fingers of each hand" (p. 20)--function as a synecdoche of Christine. Her hands, "bedizened" by the jewels, are mentioned throughout the novel: Christine spread her fingers for the familiar jolt the diamonds gave her. Then she assembled the rice, shrimp, the sauce, layering each meticulously, artfully in the casserole. It would remain warm while she tossed alight salad. Then she would arrange it all on a silver tray, take it up three of stairs, where she hoped it would choke the meanest thing in the coast. (p. 24)

The rings "snatched light from the ceiling fixture and seemed to elevate her task from drudgery to sorcery" (p. 20). Diamonds have long been thought to hold special properties; these icons of sentiment have, in addition to their role in courtship and marriage, epitomized the ideals of royalty and nobility and were even thought to prevent poisoning. Christine claimed the diamond rings won by her grandfather in a poker game, ostensibly to place on Cosey's hands in the coffin. On the surface, decorating Cosey's hands for the afterworld is a loving gesture, but pairing death with diamond engagement rings, imprinted with "other women's hopes" (p. 74) suggests the subterfuge of sentimental love. The rings, themselves a commodification of women's dreams, romanticize heterosexual relationships, which, as Cosey's poker game unmasks, are easily bargained--bought, won, and lost--by men. Christine's bold assumption of the rings is a commentary on Bill Cosey, whose sins of 
the past were obscured by the dazzling opulence of his resort and his wealth. In this way, the diamonds, representative of Cosey's assets, are a small part of his inheritance, for which both Christine and Heed vie. Christine's bold assumption of the diamonds makes visible her claim to Cosey's property.

Christine examines the damaging impact of Heed upon so-called her prestigious identity. Even as the dirty business of class prejudice in telling the stories of the Heed and Christine, she also is bent on affecting a cultural cure.

Heed and Christine, against a board history of the black experience in twentieth century America in her account of Cosey's Hotel, which thrives as an elegant and fashionable East Coast playground for wealthy blacks in the segregationist 1940s; is in decline by the integrationist 1960s; and, by the 1990s, is an abandoned ruin haunted by the Cosey's former cook, L. Examining the exclusionary politics of class in the African-American community, Morrison depicts Heed, Bill Cosey's widow, and Christine, his granddaughter, as a mortal class enemies. Even as Morrison, in telling the story, the story of Bill Cosey, exposes of power and the money of the black patriarchy, she also works to subvert it, in part, though her ghostly narrator, L, who functions as a witnesses of someone with judgment. L's hum, which is, mostly below range, comes the story of wild women who "never could hide their innocence-a kind of pitty-kitty hopefulness that their prince was on his way" (p. 4) and the story that reveals "how brazen women can take a good man down" (p. 10). This shows the property seeking attitude of brazen women in the name of love. Christine is all about money seeker, the dialogue between her and Junior pointed as: "Can I have one?" "Buy your own. You get paid. I don't. "Suppose I can't afford it, Christine." "You can afford that metal in your nose, you can afford cigarettes." "Well, I don't smoke anyway. Stinks.” (p. 130)

This discussion shows how greedy she is. Christine denies the relation between her and Junior. In the mind of Christine, there is nothing apart from money. Smoking cigarettes shows the wildness and modernity to impress guys, so guys should share the bed and she can earn more of what she needs.

Indeed, story of the novel is all about Bill Cosey and his family, Bill Cosey posses, the power of money works, "commanding beautiful man, a dollar man" (p. 43), money minded person he is. Whatever he does should follow by other or his acting is dominance: "Rich people could act like sharks" (p. 45), intention of this: is to prove Cosey as a dollar man rather than entrepreneur. Instead of this Morrison could use other terminology to show Cosey as a rich man. Indeed, novelist shows the materialistic mind of the prominent character. In the Hotel, Cosey deliberately facilitates by professional prostitutes, so raunchy guys come to have clown relax: "People with no imagination feed it, with sex- the clown of love" (p. 63). The only purpose of the hotel is to earn more money, no matter what kin of activities are done. It clearly shows swagger capitalism makes people a matter rather than spiritual. Cosey adores everybody in terms of matter and money: Mr. Cosey knew her too, although if you asked him he would deny it. Not to me, though. Mr. Cosey never lied to me. No point in it. I knew his first wife better than he did. I knew he adored her and I knew what she began to think of him after she found out where his money came from. Contrary to the tale he put in the street, the father he bragged about had earned his way as a court-house informer. (p. 67)

How the other person, here $\mathrm{L}$ is a symbol of all people, knew Cosey's wife than himself: it astoundingly shows the purpose of marring her is to capture the parental property of his father-in-law. Heed's hands, deformed, useless, burned, and arthritic, map the pain of the Cosey women's lives. 
As Cosey's child bride--her impoverished family was happy to make the deal--Heed was thrust into adulthood, had no access to education, lost her best friend, suffered the humiliation of Cosey's affairs, and was broken-hearted that a man, for whom she intended to leave Cosey, did not share her affection. Heed's hands, "small, baby-smooth except for one scarred spot, each one curved gently away from its partner like fins" (p. 28), are a testament to her disempowerment. These "fins" are alternately described as "wings" (p. 99) that "fold" (p. 141). While Heed's marriage to Cosey brought financial and sociopolitical gain, the uselessness of her hands, which are described through animal imagery, disclose her powerlessness.

The exercising of power is further illustrated through the hands of a teenaged boy, Romen. The reader is introduced to Romen through his act of compassion towards a girl: He thought her name was Faye or faith and was about to say something suddenly he couldn't stand the sight of her. If she thanked him, he would strangle her. Fortunately, she didn't say a word. Eyes frozen wide, she put on her shoes and straightened her skirt. Both of their coats, his new leather jacket and whatever she had worn, were inside the house. (p. 47)

The teenaged Romen, with six other boys, is involved in a gang rape of a young girl named Faye, yet he refuses to take his turn with this girl, shunning the brutal display of hyper sexuality and machismo. Morrison uses Faye's hands, which are curved down from the snow white shoelaces that bound them to epitomize her helplessness. Romen, intending to strengthen his phallocentric bonds, steps up to the bed, yet "watched in wonder as his hands moved to the headboard. The knot binding her right wrist came undone as soon as he touched it and her hand fell over the bedside. In the bank of the hotel, everybody wishes to be a naughty, "Go away now. This is private" (p. 78).

The private, in the plot of novel, they come on conclusion how much money to expend to share the bed. The preeminent manifestation of love, or its absence, is Cosey's composition of his last will and testament. Cosey's will, at the center of the legal and personal battle between Christine and Heed, leaves all his possessions to his 'sweet Cosey child'. Each woman believes the reference is to herself: Christine is, after all, the remaining blood relative to Bill Cosey, and Heed, who called her husband 'Papa,' claims that the term is her husband's endearment. Here, the will, scribbled on L's menu, is an example of the word made material, as it inaugurates action, the transference of property and goods. Beyond receiving Cosey's wealth, each woman vies to hold the position of Bill Cosey's sweet child: The process of will making operated in a context in which the transfer of property was interpreted as a communicative event: the giving of gifts made statements about past, present, and future relationships and was, therefore, implicated in the reproduction of relationships beyond the grave. The vast number of diamond rings on Christine's fingers takes on greater meaning as they function as multiple inscriptions of the self, registering a personal, legal, and aristocratic presentation. L's menu did indeed suture the Cosey women's lives. Sworn enemies nurtured and cared for one another until the time of their deaths. Heed, though verbally abused and taunted by May (Cosey's daughter-in-law), physically tends to her: I sat at the foot of May's bed or on top of her dresser sometimes and watched Heed soap her bottom, mash badly cooked food to just the right consistency. She cut May's toenails and wiped white flakes from her eyelids. The girl May lived to mistreat was the one she depended on to hold her head over the slop jar. Nagging her every second, but doing it: airing, cleaning, spooning, rubbing, and turning her over to the cooler side of the bed on nights hot enough to make you cry. (p. 140) 
Not only does Heed tend to May, but Christine does likewise for Heed, whose arthritis incapacitates her from performing daily tasks. Christine cooks and serves Heed's food each day, although grudgingly. It is while the women are living together that each hatches a plan for claiming Cosey's inheritance--Christine hires a lawyer, and the semi-illiterate Heed, whose "grasp of handwriting skills was limited", pays an assistant, Junior, to forge a second will, printed on another of L's menus stored in Cosey's Resort and Hotel. This will was to identify herself, without question, as the sweet Cosey child. It is fitting that Heed's trip to this memorial site would end with her death, a noteworthy confluence of handwriting, love, and death. This time, it is Christine and Heed, former best friends, who must confront the ghosts of their pasts, their love and its continuation after death. All the dramatic imitations done by Christine and May is to capture the property from Heed.

May perceives her to be a distinguishing and dirty, and potentially contaminating object. To May, Heed is "a butterfly let in through the door, already buzzing at the food table and, if it settled on Christine bound to swear her with the garbage it was born in" (p. 139).

Cosey marries Heed, May is horrified. Viewing Heed's family through the lens of class prejudice, May condemns them as a people whom: Shiftlessness was not a habit, it was a trait; ignorance was destiny; dirt lingered on by choice....the Johnson were not just poor and trifling, their girls were thought to be mighty quick in the skirt-raising department. So what must have attracted Mr. Cosey to Heed in the first place could infect her own daughter. (pp. 138-139)

Here Morrison emphasizes, in the character of Christine's mother, the shaping and the deforming influence of deeply entrenched middle-class prejudices against lower class black as neoMarxists say people are discriminated in the dipper level within same status. Conflict arise in the top level between Christine and Heed, Christine consults to lawyer how could she able to achieve the property; "May was hopeless, the place filthy, Heed's arthritis was disabling her hands, and because nobody in the town could stand them" (p. 86). Their, May and Christine, intention is to take house will not be fulfilled so they are always discussed about the parental property.

Christine knows that years are going, Indeed, she will become adult no men will not come to share their passion. So she wants to earn in the thundering age: Maple Valley, Cosey's Hotel, Manila's whorehouse- all three floated in sexual tension and resentment; all three insisted on confinement; in all three status was money. And all were organized around the pressing needs of men. Christine's second escape initiated by a home life turned dangerous was fed by a dream of privacy, of independence. ( $p$. 92)

Not only Christine most of the women need money through any work. It shows the money and property seeking tendency of the then African-American society and how the people were commodified/ materialized in the name of civilized attitude. We can carry through the dialogue of Christine; Morrison is forcefully able to make 11 years old Heed's intention of marrying with her grandpa was to take the property. "One day we played jacks; the next she was fucking my grandfather. One day this house was mine; next day she owned it" (p. 132). The deliberate use of word 'owned' means Morrison wants to justify the little lady, Heed, seeks the property of Cosey; doing intercourse with Cosey in the premenstruation age.

Morrison's Love represents the effects of trauma as a temporal disorder. The traumatic rupture of Heed's childhood with the friendship of Christine which followed upon her premature marriage to 
be Christine's grandfather disabled both girls' ability to respond appropriately to the offerings of time: like Freud's Emma, they always come too early or too late to life's events. The paradigmatic scene of temporal incongruity in Love--the prototype for all succeeding moments of temporal misfit--is the picture of Heed's honeymoon: Every day for three days they shopped, [her husband] letting her buy anything she wanted, including Parisian Night lipstick....high-heeled shoes, ... and fishnet hose. Only in the evening was she alone, for a few hours while he visited friends, tended to business. None of which Heed minded, because she had coloring books, picture magazines, paper dolls to cut out and clothe. (p. 128)

This scene comes as a shock to the reader, indeed, all that a romantic marriage could be. The conflation of honeymoon with paper dolls and coloring books emphasizes the temporal contradiction condensed in the figure of child-bride. On one hand, Cosey is male prostitute; this is the unspoken identity by all characters, on the other he acts as a husband of Heed, 11 years old lass, biologically which is fakery.

It is the forced entry into patriarchy and premature sexuality that put them off course, that made their attention swerve from the thing that mattered (their friendship) to the only thing that seemed to matter--what the man wanted. But now, recentered in their friendship, reflecting on the past from the regained perspective of the pre-heterosexual world, they can see the enormity of Bill Cosey's actions and name them, accurately, as a crime as a theft of childhood, and more.

Yet the reconciliation of the women raises questions about the deferred actions of the plot. First, why is the understanding of the original situation deferred for fifty years? My answer would be that once the premature marriage thrust both little girls into the world of patriarchal heterosexuality, they became locked into a system of meaning that robbed girlfriend love of value and made the only love that signifies the love of a man. According to this world view, the man is the central figure of importance, and the woman's task is to capture his favor, or his support, or, in the romance plot, his love. While Bill Cosey was alive, all the women, May (Christine's mother), Christine, and Heed-revolved endlessly around the enigma of the man's desire, each claiming the place of the beloved: Each had been displaced by another; each had a unique claim on Cosey's affection; each had either 'saved' him from some disaster or relieved him of an impending one. The only difference about this preburial quarrel was L, whose normal silence seemed glacial than because there was no expression on her face, no listening, no empathy-nothing. (p. 98)

The singular 'each', 'each', 'each' sketches the isolation of each woman estranged from the others by their competition for the only subject of importance, the man. And a question inevitably arises, Bill Cosey died twenty-five years before the present moment, and the women have been living together in the Cosey house for some twenty years: why did they not rediscover each other and renew their childhood love before? Counting only the twenty years they have been living together under one roof. Morrison expands the time frame to make a point, to illustrate the force of patriarchal discourse: after Cosey's death, Heed and Christine remain preoccupied with the signifiers of capitalist patriarchy, with the terms that the Law of the Father endows with meaning: inheritance, property, legitimacy. Repeatedly, Heed and Christine identify their positions within a patriarchal domestic order-Heed insisting redundantly that she is Bill Cosey's lawful wedded wife and Christine going to law to establish, again redundantly, that she is "the last, the only, blood relative of William Cosey" and hence 
the 'sweet Cosey child' his will designates as heir (p. 95). Within the patriarchal order, Christine and Heed can see each other only as rivals--first for the man's favor, then for the man's estate. It is only from a retrospective vantage-point in a changed frame of reference that Heed and Christine can perceive the real relations of power that prevented their living full lives. The text's disjunctive temporal schema exaggerates the schism. Cosey has achieved financial success in a world that systemically deprives black men of the patriarchal position.

\section{Conclusion}

Morrison's Love talks about the post-war African-American tendency to step in the commodification of human beings. Heed, along with all characters is obsessed with material possession. No doubt, Cosey, Heed and Christine are committed in doing anything for the sake of their ambition. Mr. Cosey operates Hotel and Resort where matter determines everything. Morally, consciousness and other elements are subsidiary and money is prioritized everywhere. In fact, one should have either raunchy beauty or money in the materialistic society to survive. Regarding beauty, Cosey makes women as commodity in his hotel by selling the body of poor women to earn for their survival. Relation and adoration between Cosey and his first wife is property oriented. All property of Cosey came from his dead wife's family. So Cosey is of selfish nature constantly influenced by materialistic thoughts and action. Feelings and impression of Cosey has attempted to all living characters in the name of social and material beings in the context of immoral, self centered, money minded characters and experiences. May and Christine are made property-less people although they are living in the Cosey's house where Heed, daughter-in-law and granddaughter respectively, hold all property of Cosey. They represent the materialistic world. When plot moves ahead, Heed represents as a conscientious character. The ambition of the Cosey is to earn more money. Christine, sensual and mysterious goes, on alerting her sexual relation with different male to earn money. She really seems to have ignored all morals and customs as boundaries established against the human society. In Heed's mind, wishes to kick out Christine from the house and doesn't ready to share parental property to step granddaughter and daughter-in-law. Love is mirrored by a sadomasochistic affair between local boy, Romen, and a tough reform-school girl, Junior, who both work for Heed. In 'Father' the section mainly devoted to Christine past, Morrison condenses material that would easily provide a dozen novels for another writer.The lesson for nonwhite is as compared with how Romen's relationship with his grandfather, Sandler especially, reflects the importance of intra-class/race management, plays a significant role in his development in to strong human. Indeed, Morrison wishes for blacks, within, as Romen becomes an example of goodness from his clown and rude behavior, that can evolve when people take times and identity rationally themselves. By presenting characters with materialistic obsession, Morrison emphasizes the prevailing condition of the then existing society of America Materialistic pretending love.

\section{References}

Adams, H. (Ed.) (1992). Critical theory since Plato. New York: Harcourt, 201.

Adorno, Theodore W. (1990). Negative dialectics. London: Routledge, xix.

Althusser, L. (1970). Ideology and ideological state apparatuses. New York: Monthly Review Press.

Ball, M. (2004, March 30). A review of love by Toni Morrison. http://www.compulsivereader. com/2004/03/30/a-review-of-love-by-toni-morrison/

Fox, M. (2019, August 6). Toni Morrison, towering novelist of the black experience, dies at 88. The New York

NUTA JOURNAL, 7 (1 \& 2), 2020 : ISSN: 2616 - 017x 
Times. https://www.nytimes.com/2019/08/06/books/toni-morrison-dead.html

Fulton, Katherine L. (2009). Female sexuality in Toni Morrison's Love. Graduate Thesis and Dissertation. Iowa State University. Digital Repository, 4. https://ib.dr.iastate.edu/cgi/ viewcontent.cgi? referer $=\&$ httpsredir $=1 \&$ article $=1608 \&$ context $=$ etd

Gallego, M. (2007). Love and the survival of black community. The Cambridge companion to Toni Morrison. Justine Tally (Ed.). Cambridge: Cambridge University Press.

Gibson, Donald B. (1984). Text and counter text in The bluest eye. New York: Gates Press.

Langer, E. (2019, August 6). Toni Morrison, Nobel laureate who transfigured American literature dies at 88. The Washington Post. https://www.washingtonpost.com/local/obituaries/toni-morrisonnobel-laureate-who-transfigured-american-literature-dies-at-88/2019/08/06/49cd4d46-b84d11e9-a091-6a96e67d9cce_story.html

Manbiot, G. (2013, December 09). Materialism: a system that eats us from inside out. The Guardian. https://www.theguardian.com/commentisfree/2013/dec/09/materialism-system-eats-us-frominside-out

Marxism (n. d.). Retrieved 20 December, 2020 from https://en.wikipedia.org/wiki/Marxism

Marx, K. (1996) The communist manifesto. Creation of knowledge. Shreedhar P.Lohani, Rameshwar P. Adhikari and Abhi N. Subedi (Eds.). Kathmandu: Ratna Pustak Bhandar, 21

Mc Carthy, J. (2004). Love Magill's Literary Annual. New York: Longman, 202.

Michael, A. (1990). Unruly and let loose: myth, ideology, and gender in song of Solomon. Callaloo. Morrison, T. (2003). Love. New York: Knopf.

Parvini, N. (2012). Shakespeare and comtemporary theory: New historicism and cultural materialism. New York and London: Bloomsbury, 36.

Phillips, K. (2003, November 18). Toni Morrison: Love. https://aux.avclub.com/toni-morrisonlove-1798199083

Pun, M. (2017, July 15). Anti- racist pedagogy and the canonization of Toni Morrison. Crossing the Border: International Journal of Interdisciplinary Studies, 5(2), 15-24. ISSN 2350-8752.

Roynoon, Tessa K. (2007). A new Romen empire: Toni Morrison's love and the classics. Journal of American Studies, 41 (1), 31- 47

Rubenstein, R. (2001) Home matters: Longing and belonging, nostalgia and mourning in women's fiction. New York: Palgrave.

Schroeder, A. (1990). An Afro-American woman writer and her reviewres/critics: Some ideological aspects in current criticism of Toni Morrison's fiction. AAA: Arbeiten aus Anglistik und Amerikanistik, 15(2), 109-125

Showalter, E. (2003, November 29). Review of love by Toni Morrison. https://www.theguardian.com/ books/2003/nov/29/fiction.tonimorrison

Stewart, J. (1996). Introduction: The Hegel myths and legends. New York: North-Western University Press. 